\title{
The evolution of business relationships between technology-intensive new ventures and incumbents during the new product development process
}

Mohammad Ali Bahreini*; Ali Mobini Dehkordi`; Nima Heirati; Mohammad Reza Meigounpoory ${ }^{\S}$

\author{
* Doctoral Researcher \\ Faculty of Entrepreneurship, University of Tehran \\ 16 St., North Kargar Ave., Tehran, Iran \\ Tel. +98912 2490511 - Email: bahreini@ut.ac.ir \\ $\dagger$ Corresponding author, Faculty of Entrepreneurship, University of Tehran \\ 16 St., North Kargar Ave., Tehran, Iran \\ Tel. +98912 1301806 - Email: mobini@ut.ac.ir \\ $\$$ Lecturer in Marketing and Innovation Strategy \\ School of Business and Management, Queen Mary University of London \\ Bancroft Building, Mile End Road, London, E1 4NS, United Kingdom \\ Tel. +44 2078826612 - Email: n.heirati@qmul.ac.uk \\ $\S$ Faculty of Entrepreneurship, University of Tehran \\ 16 St., North Kargar Ave., Tehran, Iran \\ Email: meigounpoory@ut.ac.ir
}

\begin{abstract}
This study investigates how technology-intensive new ventures shape and manage their relationships with incumbents to successfully develop new products. We undertake the dynamic views of business relationship to reveal under what conditions new ventures should emphasize more on transactional contract or alliance approach to develop their relationships with incumbents. Using longitudinal multiple case analysis, we show that transactional contract is less effective during discovery and development stages to facilitate knowledge share and collaborative learning between new ventures and incumbents. However, adopting transactional contract is essential during commercialization to strengthen the relationship, minimize the drawbacks of social bonds, and motivate both parties to engage in new projects. The results show that tensions between exchange partners are likely to increase when the incumbent is flexible to re-negotiate and share the fair benefits during the commercialization stage. Our findings provide new insights about the evolution of new ventures' relationships with incumbents across NPD stages.
\end{abstract}

Keywords: Business relationships, new ventures, incumbents, new product development, longitudinal case study 


\section{Introduction}

Collaborative new product development (NPD) is extensively recognized as an effective innovation mode for many firms (Schleimer and Faems 2016). NPD collaboration is defined as a close business relationship between two or more firms involved in the development and commercialization of a new product/service (Marion et al. 2015; Heirati and Siahtiri 2017). NPD collaboration represents a pecuniary form of open innovation, where two or more firms engage in ongoing co-creation of knowledge (i.e., coupled inbound and outbound processes identified by Enkel et al. 2009). NPD collaboration offers multiple potential benefits such as the reduction of development cost, seizing of market opportunities, and creating new knowledge for firms that lack the necessary resources and know-how (Schleimer and Faems 2016). The entrepreneurial literature also stresses the role of business relationships by arguing that new ventures (also called entrepreneurial firms or start-ups) often lack the resources and knowledge needed to successfully turn their innovative ideas to commercializable new products (Haeussler et al. 2012; Pérez et al. 2012). This stream of research provides the evidence that many disruptive innovations, such as nanotechnologies and biotech with the potential to change many industries, are commonly initiated by technology-intensive new ventures (Carayannopoulos 2009; Genet et al. 2012). Given the substantial costs and risks associated with disruptive innovations, technology-intensive new ventures may collaborate with incumbents (i.e., large firms with the established position in the market) to overcome resources deficiency and provide the foundation for collaborative innovation (Rothaermel and Thursby 2007).

Business relationships with incumbents provide unique opportunities for new ventures to overcome cost and risks associated with NPD (Carayannopoulos 2009). However, managing these relationships is challenging due to the liability of smallness of the start-up firm and asymmetric structural power of the incumbent (Pérez et al. 2012). It is advocated that while incumbents have extensive resources to invest in NPD projects often lack organizational flexibility and innovativeness to develop disruptive technologies (Rothaermel and Thursby 2007). There is evidence that many incumbents through collaboration with or acquisition of other smaller technologyintensive firms can gain advanced technology necessary to stay up-to-date and introduce new products to the market (Pérez et al. 2012). Therefore, building effective business relationships between technology-intensive new ventures and incumbents represent a critical determinant of successful collaborative NPD. Despite the advances in the collaborative innovation literature, two key questions remained unanswered regarding how new ventures develop asymmetric business relationships with incumbents and manage their relationships to successfully develop new products.

First, the extant innovation literature suggests that firms need distinct resources and competence for each NPD stages (i.e., discovery, development, and commercialization). Therefore, new ventures and incumbents may collaborate to gain resources and know-how required for a single stage or develop an ongoing relationship across the entire NPD stages. It is advocated that firms (i.e., new ventures) commonly adopt one or a combination of transactional and relational governance approaches to developing business relationships (Palmatier et al. 2007). The transactional approach stresses the role of transactional contracts to safeguard business partners against contractual hazards when firms outsource non-core operations to business partners to minimize their operating costs and focus on core capabilities (Cao and Lumineau 2015). In contrast, the relational approach relies on informal structure, mutual trust, and commitment to facilitate knowledge share and collaborative learning between exchange partners (Palmatier et al. 2007). Relational governance mechanisms are essential to building alliances involved collaborative learning and joint innovation (Panico 2017). Despite advances on the determinants of 
business relationships, little is known how do new ventures undertake transactional contracts or alliance approach to build business relationships with an incumbent to transform their patents to commercializable new products?

Second, recent advances in the literature show that business relationships evolve, and their benefits may follow an inverted U-shaped trajectory over time (Palmatier et al. 2013; Heirati et al. 2018), unless exchange partners undertake alternative governance tactics to adjust and maintain their relationships (Zhang et al. 2016). This perspective is particularly critical in the context of NPD collaboration, where the relationships between business partners may change across different stages. In particular, new ventures that may engage in asymmetric relationships with powerful incumbents during the discovery stage to survive and access external resources required to develop new products (Carayannopoulos 2009; Oukes et al. 2017). When a new venture grows and acquires resources and skills from the incumbent during the NPD process, the unequal structural power and distribution of outcomes may lead to their dissatisfaction and tendency to adjust or leave the current business relationships at later NPD stages. Therefore, it is likely that new ventures and incumbents undertake alternative governance approaches across different NPD stages. However, limited attention is given to when new ventures emphasize more on transactional contract and alliance approach to adjust and improve business relationships with an incumbent across different NPD stages (i.e., discovery, development, and commercialization)?

Our study aims to address these research questions and advances the literature in two ways. First, unlike the extant literature that commonly argues business relationships will move from transactional contract or alliance approach over time (e.g., Marion et al. 2015; Heirati et al. 2018), we show that the relationships between new ventures and incumbents may follow diverse trajectories under different circumstances. Using a longitudinal multiple-case analysis, we find that while new ventures commonly tend to undertake transactional contracts to reduce knowledge leak during the discovery stage, they are forced to change their approach by the incumbent due to the asymmetric structural power. During the development stage, new ventures undertake the alliance approach and relational governance mechanisms to gain the incumbent's trust, commitment, and complementary resources. When new ventures prove their innovation capabilities by the successful development of prototypes, they will gain more legitimacy and negotiation power. Consequently, new ventures during the commercialization stage will attempt to undertake transactional approach again to adjust their relationship and re-negotiate exchange parties' role and fair distribution of relationship outcomes. Our findings extend the work Marion et al. (2015) by showing how the transition from alliance approach to transactional contract is necessary to strengthen the relationships and minimize drawbacks of social bonds.

Second, we show that when incumbents stick to the initial contract that the new venture was forced to accept at the discovery stage, the likeliness of conflicts and less transparent behavior will be increased. Our findings show that when new ventures undertake a conciliatory approach by emphasizing the value of long-term relationships and avoiding hostile negotiation tactics, the incumbent is more likely to respond well and reconsider its position. However, the hostile negotiation approach may harm the relationship performance and continuity. Therefore, our study advances the understanding about the importance of transactional contract approach to renegotiate the collaboration terms and expectations at the final stage of a collaborative NPD. We extend the works of Pérez et al. (2012) and Oukes et al. (2017) by showing that under what conditions new ventures can successfully undertake power change behavior and re-negotiate their transactional contract. 
Our paper proceeds as follows. The next section reviews the literature on business relationships and opportunities and threats of relationships with incumbents. We then outline the research methodology and present results. Finally, we discuss theoretical contributions and managerial implications of our study.

\section{Literature Review}

\section{Collaborative new product development}

Successful development new, innovative products are paramount for the firm's success and survival across different industries. However, the evidence regarding the high failure rates of new products creates a dilemma that manifests both practical and theoretical concerns about antecedents of successful NPD. In the pursuit of addressing this dilemma, the extant literature views the collaborative innovation as the determinant of successful NPD (Sivadas and Dwyer 2000; La Rocca et al. 2016), particularly in the context of disruptive innovations, such as nanotechnology and biotech (Mangematin and Walsh 2012). Nanotechnology, for instance, is a technologyintensive interdisciplinary area with tremendous impact on several industries. Nanotechnology involves groundbreaking scientific research (i.e., disruptive innovations) to increase efficiency in traditional industries (Mangematin and Walsh 2012). In this sense, the growth of disruptive innovations may threaten the leadership of established firms and their investments in existing wave of technologies, while it creates emerging opportunities for new ventures (Ansari and Krop 2012). Such new entrants are in a better position to take advantage of disruptive technologies than incumbents, who may suffer from organizational inertia and face the prospect of having to cannibalize their own markets (Genet et al. 2012).

There is evidence that many disruptive innovations (i.e., nanotechnologies, biotech) are developed by research-intensive new venture (i.e., university spin-offs backed by venture capital) that aimed to transform scientific patents to new products (Genet et al. 2012). However, these new ventures commonly lack critical resources in areas, such as manufacturing, marketing, and distribution network, to transform their patents into commercializable innovations (Carayannopoulos 2009; Haeussler et al. 2012). Disruptive innovations also involve high cost and failure risk, where collaboration with established firms (or incumbents) that possess required resources to invest in NPD (Genet et al. 2012). Such collaboration between new ventures and incumbents help both parties to gain resources they lacked: New ventures share their scientific discoveries with incumbents to develop new products, whereas incumbents enable new ventures to transform their patents to commercializable new products and receive royalties (Genet et al. 2012).

\section{Opportunities and threats of business relationships with incumbents}

There is a growing literature on the new ventures' liabilities of smallness and newness and the importance of business relationships to access complementary external resources (Padula 2008; Pérez et al. 2012). It is advocated that business relationships with incumbents can compensate the new venture liability smallness, provides endorsement, and facilitates access to complementary external resources (Pérez et al. 2012). Such business relationships provide available infrastructure in which the new venture can develop novel inventions using the incumbents' resources and competencies (i.e., financial, human resources, equipment, and distribution channel) (Genet et al. 2012; Pérez et al. 2012). Incumbents are generally large-sized, stable organizations, rich in resources, with well-proven technical and operational routines and procedures, and have extensive knowledge and 
experience (Ansari and Krop 2012). They emphasize explicit long-term relationships with upstream new ventures to provide advanced technology and knowledge, necessary to keep on up-to-date (Pérez et al. 2012).

Business relationships not only facilitate knowledge transfer between new ventures and incumbents but also form and generate new knowledge which none of the parties earlier possessed (Grant and Baden-Fuller 2004). However, there is evidence that new ventures and incumbents are different regarding their goals, dependence on external partners, structures, and decision making (Pérez et al. 2012), which can raise disagreements about what and how to develop the relationship. This issue is especially important in the context of technology-intensive new ventures, because of considerable investment and failure risks associated with developing innovative products (Carayannopoulos 2009). On the other hand, technology-intensive new ventures are seen as "technologybringing" incubates that help incumbents to acquire new patents and knowledge necessary to stay up-to-date and competitive in the market (Genet et al. 2012). Thus, creating successful business relationships is vital for both new ventures and incumbents to collaboratively develop new products.

\section{Transactional contract and alliance approaches}

The literature has suggested that firms commonly adopt one or a combination of transactional and relational governance approaches to develop business relationships (Palmatier et al. 2007; Heirati et al. 2018). Transactional approach is built on the transaction cost economics (TCE) and emphasizes the role of transactional contracts (i.e., outsourcing, franchising, licensing) as a formal mechanism to safeguard business partners against contractual hazards (i.e., opportunism and conflict). Transactional contracts are commonly employed for outsourcing nonecore activities to other firms to minimize operating costs and help the focal firm to focus on its core capabilities (Cao and Lumineau 2015). Transactional contracts also represent a legal and protective approach when firms tend to minimize the knowledge leak to their business partners (Hagedoorn and Hesen 2007). Transactional contracts commonly define the expected outputs, monitoring mechanisms, and the exchange partners duties and rights (Cao and Lumineau 2015). Nevertheless, it is advocated that transactional contracts are less effective to develop business relationships that are built on mutual trust and collaborative learning, such as joint research and development (R\&D) (Cao and Lumineau 2015; Marion et al. 2015).

Relational approach refers to the extent to which a business relationship is governed by social and relational norms, such as mutual trust, commitment, and interdependence (Palmatier et al. 2007; Panico 2017). This approach building on the social exchange theory (SET) relies on informal structure and self-enforcement of each party (Cao and Lumineau 2015). It focuses on building mutual trust and commitment to facilitate knowledge share and collaborative learning between exchange partners (Palmatier et al. 2007). To prove trustworthiness and commitment, exchange parties will regularly invest in the relationship beyond the contractual obligations. Cooperative parties should follow the rules of reciprocity to nurture mutual trust and relational norms (Cao and Lumineau 2015). Relational governance mechanisms such as mutual trust and commitment are advocated as an effective approach to build alliances involved collaborative learning and joint innovation (Panico 2017). However, relational approach is subject to several limitations. Relational norms take considerable time to be developed and are likely to be destroyed by opportunistic behavior and betrayal in a short time (Zhang et al. 2016). Unlike transactional contracts, relational norms are less transparent and can be abused by opportunism when formal monitoring is replaced by the excessive trust (Jap and Anderson 2007; Marion et al. 2015). 
Although the relational and transactional governance approaches have different centers of attention, the extant literature shows that both types of mechanisms are necessary to successfully develop business relationships. Despite the extensive literature on the role of relational and transactional approaches (see literature summary in Table 1), little is known when firms should emphasize more transactional contracts or developing alliance to succeed in their business relationships. This challenge is critical for the asymmetric relationships between new ventures and incumbents that are commonly characterized by dissimilarity between exchange partners in terms of resources and structural power (Pérez et al. 2012; Oukes et al. 2017).

\section{--- Insert Table 1 Here ---}

\section{Evolution of business relationships}

Although most of the extant studies are based on a static perspective of business relationships, there is growing attention to the dynamic nature of business relationships and how they evolve over time (Marion et al. 2015; Heirati et al. 2018). This stream of literature shows that business relationships' characteristics and exchange partners behavior change over time through repeated interactions (Palmatier et al. 2013). This perspective is based on the fact that close relationships characterized by mutual trust, commitment, and social bonds take time to be developed (Heirati et al. 2018). It is argued that business relationships evolve beyond transactional exchanges when partners are required to engage in collaborative learning activities and joint research and development projects (Marion et al. 2015). Although evolving from a transactional contract to an alliance is necessary to shape long-term relationships, little is known under what condition exchange partners shift across transactional and alliance approaches over time.

It is advocated that the development of business relationships is not linear and exchange partners over time may become more sensitive to costs and benefits of a relationship when there are alternative business partners (Heirati et al. 2018) and their exchanges are less transparent and fair (Pérez et al. 2012). Consequently, the benefits of a business relationship may follow an inverted U-shaped trajectory over time (Villena et al. 2011), unless exchange partners undertake new governance mechanisms to adjust and maintain their relationships (Zhang et al. 2016). This perspective is particularly critical in the context of new ventures that may engage in asymmetric relationships with powerful incumbents to survive and access external resources required to develop new products (Carayannopoulos 2009; Pérez et al. 2012). For instance, Marion et al. (2015) show that new ventures commonly undertake the transactional contract to initiate relationships with their partners and gradually shift towards alliance approach to expand their relationships, build emotional-social bonds, and engage in collaborative learning. While their study shows that strong emotional-social bonds lead to reliance on implicit and less transparent agreements that could diminish the benefits of a relationship, little is known how and under what conditions new ventures can undertake different governance approaches to adjust and maintain their relationships over time.

\section{Research Methodology}

\section{Research design}

We employed longitudinal multiple case study following the approach suggested by Yin (2014) to explore the evolution of business relationships across different stages of a collaborative NPD. Longitudinal multiple case studies are effective and helpful for detailed information and rich and deep empirical data (Eisenhardt and Graebner 2007) and are an appropriate tool for investigating the evolution of business relationships over time (Marion et al. 2015). Employing the case study approach specifically allows us to use varied sources of data (i.e. 
interviews, observation and on-site visits, and review of reports, contracts), and to use in-depth interviews with new ventures' executives to generate new insights for research on how and when new ventures undertake different governance mechanisms to develop and adjust relationships with an incumbent across different stages of a collaborative NPD.

Eisenhardt (1989) asserts that it is difficult to develop theory and insights from less than four cases and it would also be difficult to manage and analyze data from more than 10 cases. The appropriate number of cases will be determined by how much each adds incrementally. In our study, the a priori variation in characteristics was achieved with seven cases of technology-intensive new ventures that collaborate with incumbents to develop and commercialize nano-based new products. We followed several selection criteria to identify and invite respondents. First, all studies new ventures were technology-intensive start-ups founded over last one year, in the context of nanotechnology. Nanotechnology involves ground-breaking scientific research (i.e., disruptive innovations) and represents a technology-intensive interdisciplinary area with tremendous impact on several industries (Mangematin and Walsh 2012). Therefore, collaboration with incumbents is critical for new ventures to overcome high cost and failure risks associated with disruptive innovations (Genet et al. 2012). Second, respondents had new patents and intended to transform their patent to commercializable new products in collaboration with an incumbent (i.e., a large-sized firm with a stable position in the market). All studied cases were members of the Iranian Nanotechnology Network (INN), which is controlled and supported by the government. As noted above, seven new ventures from this database met the specified selection criteria and accepted to participate in this study by share information regarding their collaborations with an incumbent across different stages of a collaborative NPD. Table 2 presents a summary of the studied ventures' characteristics. All studied new ventures were founded during 2010 to 2011 by founders' capital or use of governmental (i.e., INN) loans.

\section{--- Insert Table 2 Here --.}

\section{Data collection}

We investigated seven NPD collaboration cases from the initiation to completion over a period of 8 years (20102017). The unit of analysis was new ventures that collaborate with incumbents to develop a new product. Case study research has been criticized for different forms of bias and subjectivity associated with the data interpretation and analysis (Yin 2014). We applied triangulation using data combined from different sources to reduce the bias and to gain a more complete and objective picture of the subject of analysis (Hienerth et al. 2014). We conducted 44 semi-structured interviews with executives (i.e., founder, CEO) and visited studied new ventures every sixmonth period over eight years (twist a year during 2010-2017) to receive updates regarding the studied business relationship and NPD project. The interviews started with questions about how business relationships between technology-intensive new ventures and incumbents are initiated, how their relationship characteristics are evolved during discovery, development and commercialization stages, what had been argued or discussed during these stages and what interactions and activities had taken place. The research team then proceeded to investigate relationship characteristics and governance mechanisms discussed in the extant literature (i.e., transactional contract or alliance approach, symmetric or asymmetric dependence, trust, commitment, and relational norms). There were also questions about the new venture's innovation capability and flexibility to satisfy incumbent's demands. The interviews concluded by asking respondents to discuss other challenges and opportunities involved in the collaborative NPD. Each interview lasted 30-45 minutes, and all interviews were recorded and transcribed. 
Finally, asked respondents to review and verify the recorded transcripts to assure the accuracy of the interview data (Creswell 2007). Furthermore, we processed secondary data through on-site visits and reviewing the studied new venture's website, reports, and contracts. Table 3 outlines the studied business relationships and their outcomes. In 2017, six of seven studied cases successfully developed and commercialized new products and one case failed to manage the collaboration with the incumbent and bankrupted.

\section{--- Insert Table 3 Here ---}

\section{Data analysis}

Qualitative case study data analysis includes precise examination, codification, combining data, extracting the results in two main activities, analysis of each case and cross-case analysis (Yin 2014). First, we developed a data file for each case, listing the characteristics of the collaborative NPD project and the relationships with the incumbent. Second, we applied data coding following three steps suggested by Hienerth et al. (2014). In a first step, we drew on literature to identify major determinants of the collaborative NPD (i.e., NPD stages requirement, governance mechanisms). In a second step, we develop codes within the identified concepts in the first step within each case. Two researchers independently reviewed each case to understand, extract, and distinguish codes raised within interviews in separated tables. Then, the differences were compared and identified codes were groups and transferred into a unified table. In the third step, we performed cross-case analysis by matching patterns (i.e., the evolution of business relationships between the new venture and the incumbent) across seven cases. Following cross-case analysis, we developed a model (Fig. 1) to outline the evolution of business relationships across different stages of NPD and to identify overlaps and gaps between the data and the extant literature. In this process, we continuously used the technique of pattern matching to move back and forth between the data (i.e., identified codes and trends) and possible theoretical explanation to improve the credibility analysis (Eisenhardt 1989). Following Creswell (2007) and Yin (2014), we presented the findings through a report to respondents to ensure that validity of reported findings and controlling any pre-existing bias of the researchers. The findings were approved by respondents with minor suggestions.

\section{--- Insert Fig. 1 Here ---}

\section{Descriptive Results}

This section presents descriptive findings related to how the business relationships between new ventures and incumbents evolve across NPD stages of discovery, development, and commercialization stages. The discovery stage includes the initial market check, ideas conceptualization and ensuring of its acceptable (Barczak et al. 2009). In the development stage, the details are designed and in commercialization stage activities such as premanufacturing, market test, first sale and creating capacity for manufacturing are performed (Barczak et al. 2009). We summarized the evolution of studied business relationships throughout NPD stages in Table 3 . Figure 1 illustrates the studied relationships evolution trajectory across NPD stages. We found that all studied business relationships shift from transactional contract to alliance approach in the discovery stage. They will follow the alliance approach during the development stage until the first prototypes are successfully developed, the levels of dependence and RSIs become relatively symmetric between both parties, and mutual trust and relational norms are established. In the commercialization stage, new ventures gradually undertake transactional approach again to re-negotiate their business relationships terms and ensure that each party receives fair benefits. Shifting from alliance approach to transactional contract in Figure 1 does not reflect whether the strength of relationships 
between exchange parties is changed. Although alliance and transactional contract are distinct, we view them as distinct approaches that new ventures undertake to develop and nurture their relationships with the incumbent.

\section{Discovery stage}

It is advocated that new ventures commonly undertake transactional contract to start relationships with incumbents, particularly during the discovery stage (Marion et al. 2015). The transactional contract helps to outsource non-core activities (i.e., manufacturing a component) and minimize the cost of design and prototyping processes. As shown in Figure 1, we find that this approach was evolved, and new ventures undertake the alliance approach during the discovery stage for several reasons.

First, the incumbent in some cases forced the new venture to shift from transactional contract to alliance approach. We find that while new ventures tend to outsource non-core activities to other firms (i.e., other smallsized suppliers or incumbent partners) to protect their patents and avoid knowledge leak, this view is inconsistent with an incumbent to engage in a relationship. For instance, it was stated by Respondents A and C that: “...the incumbent lacked the necessary information about our patents and constantly asked for more details that were confidential from our perspective.” Incumbents commonly undertake acquisition or long-term alliance approaches to possess patents and new knowledge developed by new ventures (Carayannopoulos 2009; Ansari and Krop 2012). The acquisition occurs when a new venture's patents are critical for the incumbent to stay competitive in the market and their competitors search for comparable technologies. When new ventures refuse to sell their business, the incumbent may undertake alliance approach to develop strong relationships and increase the new venture's switching cost to move from the relationship. We find that incumbents not only invest more in the relationship to incentive the new venture, but also force the new venture to commit more resources and share their patents (see arguments on asymmetric relationships in Pérez et al. 2012). Consequently, the incumbent can shape the relationship and force the new venture to accept their terms, especially when the new venture's lack negotiation skills (see arguments on negotiation power in Oukes et al. 2017). All new ventures in our study shift to alliance approach and accept the incumbent's requests due to lack of experience and substantial reliance on the incumbent's resources required for NPD. For example, Respondent B indicated that “...the incumbent had the necessary facilities and processes to develop and test the new product. Possessing these resources was vital for us to grow and survive."

Second, both new ventures and incumbents through interactions in the discovery stage gain a better understanding of each other's complementary resources and the fact that each exchange partner cannot develop the new product independently (see Grant and Baden-Fuller 2004). For instance, Respondent A stated that: “...we lacked the necessary information about incumbents and their resources and abilities and on the other hand they did not the good knowledge of our patents application. Throughout the process, accurate recognition of each other was made over time." This view is rooted in the resource dependency theory, where exchange partners gradually decide to rely on each other to enhance the relationship performance. We find that new ventures may have some views regarding the application of nanotechnology, but very limited knowledge of how to transform their patents to commercializable products (see Nikulainen 2010). Respondent A stated that “...we need the incumbent's resources and experience to understand how nano-fibers can turn to automobile filters." Respondents B and C also indicated that the combination of their patents and the incumbent's resources help understand further applications of their patents. Respondents D and E emphasized the "synergy" between their knowledge and the 
incumbent experience as the trigger for developing new products. On the other hand, the incumbent may have a limited understanding of the nanotechnology application to their product lines. Collaboration with new ventures enables incumbents to possess new knowledge and capabilities to develop new products (Perez et al. 2012). Therefore, both parties may encourage each other to move beyond the initial contract and undertake alliance approach to expand their relationships. Moving towards building alliance with an incumbent over time is advocated in the literature (e.g., Marion et al. 2015) as in our interviews with new ventures. For instance, Respondent A indicated that: “...we lacked the necessary knowledge and resource we could do nothing without collaboration with the incumbent." Respondent D noted that “... we gradually worked more closely to know each other and shared all of our technical information."

Third, new ventures may have an inaccurate understanding of the incumbent's internal processes and standards during the discovery stage. For instance, Respondent $\mathrm{C}$ asked the incumbent to avoid excessive obsession and tests, while the incumbent believes that new ventures should focus on only their technological activates rather than market-testing the prototypes. Respondent $C$ later realized that the incumbent's view was correct, and gradually gained a better understanding of the incumbent's experience and capabilities. Respondent C noted that: " ...the degree of their sensitivity through the discovery stage was very high, where they raised their concerns regarding the collaborative NPD project. Through ongoing interactions, we better understand underlying reasons for their concerns." Through ongoing interactions, exchange partner will become familiar with one another, share their concerns, and thereby develop mutual trust and relational norms (Palmatier et al. 2013). Mutual trust and relational norms between exchange partners also help to align expectations, resolve disputes, and build a cooperative relationship atmosphere (Villena et al. 2011). When a new venture ensures that the incumbent's suggestions will be used for the mutual benefit of both parties, they will engage with the incumbents more effectively. Developing mutual trust and social bonds also motivate incumbents to allow new ventures to use their experience, human capital, and equipment (Padula 2008). Therefore, exchange parties through ongoing interactions may increasingly rely on relational mechanisms, as opposed to contractual mechanisms, to develop their relationship (Jap and Anderson 2007). This shift is advocated in the literature (e.g., Padula 2008) as in our studied new ventures. For instance, Respondent E noted that: “...when the incumbent trust us and our innovation capability, it provided all necessary resources, technological know-how, and market knowledge along with their design and production teams to develop the new product."

Although most of the studied new ventures undertake alliance approach quickly during the discovery stage, some new ventures avoid expanding relationships due to flaws in initial contracts, unanticipated challenges during NPD, and lack of mutual understanding and trust between exchange partners (see also Palmatier et al. 2007). This protective behavior is based on the new venture's lack of experience in terms of negotiation skills, inability to identify the incumbents' capabilities, concern about intellectual property, and overestimating the value of technology (Perez et al. 2012). The incumbents' staffs were usually more experienced, but less creative and flexible to adapt their views than the new ventures' staff. Consequently, exchange partners may spend considerable time to create a common language and clarifies NPD processes and requirements to minimize tensions and dysfunctional behavior. For instance, Respondents D and F indicated that “...the incumbent employees were not familiar with the scientific terms and could not address our questions correctly. They often provided inaccurate information, and we should spend considerable time to train them regarding the application of our patents to their industry." 
We conclude that the nature of relationships between new ventures and incumbents evolve during the discovery stage at the different pace as exchange parties move beyond a transactional and less collaborative contract. While both parties in some cases gradually adopt alliance approach (i.e., Respondents A and B), some new ventures suddenly undertake this approach to satisfy the incumbent's requirement (i.e., Respondents C, D, and E). Although adopting alliance approach facilitates access to complementary resources, collaborative learning, and mutual commitment (see also Haeussler et al. 2012), most of the studied new ventures are pushed to share their patents and knowledge with the incumbent. This behavioral change was challenging as new ventures could not protect themselves from knowledge leak and engage in an asymmetric partnership, where their RSIs and dependence were much higher than the incumbent. For instance, Respondent F noted that: “...we shared the necessary experience and knowledge with the incumbent managers to trigger their motivation and dedication to involve more in the NPD process.” Respondent G indicated that “... we had limited choices. We should be trusted [by the incumbent] to access resources required for NPD." Figure 1 and Table 3 outline the studied relationships' characteristics and evolution during the discovery stage.

\section{Development stage}

All of studies new ventures passed the discovery stage successfully and expanded their relationships through developing a close strategic alliance with the incumbent in the development stage. The complexity of developing final prototypes, particularly in the context of disruptive technologies, increase the need for human and financial resources during this stage (Mangematin and Walsh 2012). In particular, design teams from both parties worked together for long hours, and the frequent telephones and emails became part of involvement managers' daily routine. For instance, Respondent A stated that the incumbent "contributed more resources and efforts when their managers understand the design challenges and requirements." We find that additional contribution and guidance by incumbents are particularly critical during the development stage because of their accumulated experiences and knowledge of how to resolve bottlenecks and operational challenges. Increasing contribution and commitment from both partners led to tolerance of failures and progress in the product development (see comparable arguments in Haeussler et al. 2012). Respondents B and D indicated that "the incumbent cooperated closely with us for prototyping and committed further resources required to create, test, and improve prototypes." Respondent C noted that "detail design and engineering of nano-diamond auto oil concentration was very complicated, and we could not do it without the experienced and collaboration of the incumbent." Respondents F and G indicated that "the incumbent insisted on something that we have ignored them before due to lack of experience. The collaboration with the incumbent lead to substantial upgrade of the NPD process."

While most of the new ventures were concerned about technical knowledge leak during discovery stage, mutual trust and commitment help both partners to promote collaborative learning and developing knowledge and ideas that none of the parties could develop independently (see also Haeussler et al. 2012). In some cases, a new venture's managers also share knowledge and advice regarding other incumbent operations that are not directly related to the NPD project (see comparable findings in Marion et al. 2015). At this stage, new ventures mostly tended to have stronger and more stable alliances with incumbents. For instance, Respondent E indicated “...we were all joined up together to achieve our common goal for designing water clarification and heavy metals removal from drinking water." We conclude that the nature of business relationships at the end of discovery and during development stages remain relatively unchanged. Both exchange parties undertake alliance approach and 
relational governance mechanisms (i.e., mutual trust, commitment, relational norms) to strengthen their relationship and achieve common objectives.

\section{Successful relationships during the commercialization stage}

During the commercialization stage, the initial product designs are tested, finalized, and ready to be commercialized. The key challenge in this stage is the proper positioning of developed new products in the incumbent's operations, which required a lot of effort and interaction to improve and calibrate the final product (see similar arguments in La Rocca et al. 2016). Despite the increasing interactions and strong relationships between both parties, most of the studied new ventures consider undertaking transactional approach again to adjust both parties' responsibilities (i.e., product support and maintenance) and expected financial benefits. This finding is in contrary to the existing research that shows the business relationships between new ventures and incumbents commonly moves only from transactional contract to alliance (Deeds and Hill 1998; Ring and Van de Ven 1994; Marion et al. 2015). Our findings reveal that new ventures undertake transactional contract approach during the commercialization stage for several reasons.

First, new ventures have acquired the necessary capabilities, gained legitimacy, and reduced dependence on the incumbent during the commercialization stage. Therefore, new ventures will benefit from stronger negotiation power and a better understanding of the incumbent's capabilities and limitations compared to the discovery stage. Our findings are consistent with the work of Oukes et al. (2017) that suggest new ventures may undertake tactics to change power asymmetry in their relationships over time. In this sense, new ventures may request to developing a new contract to ensure each partner received a fair distribution of alliance benefits and set a structure of their interactions (i.e., product maintenance and improvement). For instance, Respondent A offered a new contract to the incumbent to "outsource the production and commercialization activities to the incumbent and focus more on its scientific core innovation activities...the new contract helps to ensure continuity our relationships with the incumbent." Respondent D stated that “...after initial production of hard coating and confirmation of qualitative test, we [our firm and incumbent] agreed to make a new contract to redefine each party's roles and expectations." Respondent G indicated that "we asked the incumbent to place new orders based on the new contract that provide fair financial benefits for both parties." Our findings extend the work of Oukes et al. (2017) that argue exchange partners gradually gain a more accurate perception of one another's power, needs, and capabilities. We find that new ventures may overestimate the structural power of the incumbent and dependence of incumbent on their innovation capability in early stages of NPD. Through interactions during discovery and development stages, the new venture may realize how much their patents are critical for incumbents to address technological turbulence and competition in the market. New ventures compared to established firms may lack the experience to properly assess the benefits of a relationship, but they learn over time, re-evaluate the benefits of a relationship, and may identify alternative business partners.

Second, we find that ongoing relationships between exchange parties help to form socio-emotional bonds (see also Marion et al. 2015; Heirati et al. 2018). Although there is evidence regarding the dark-side of excessive trust and emotional bonds in business relationships (e.g., Jap and Anderson 2007; Marion et al. 2015), our findings show that socio-emotional bonds and mutual trust help partners to renegotiate their position in the relationship and develop new contractual terms to maintain their relationships. Importantly, undertaking transactional contract approach during the commercialization stage helps to minimize drawbacks associated with socio-emotional bonds 
identified by Marion et al. (2015), increase the transparency, and adjust expectations from each party. As illustrated in Figure 1, we conclude that new ventures undertake transactional contract approach at the final stages of NPD (solid black line in Fig. 1) to re-negotiate their partnership's expectations, share responsibilities, and ensure both partners receive the equal distribution of alliance benefits. We find that only Respondents $\mathrm{C}$ and its incumbent did not reach a contractual agreement at the beginning of the commercialization stage and terminated their relationships (grey dash line in Fig. 1).

\section{Damaged relationships during the commercialization stage}

We observed that only Respondents $\mathrm{C}$ failed to reach to the commercialization stage, terminated collaboration with the incumbent, and bankrupted. A key reason for termination of this business relationships was the Respondent C's perception of asymmetric relationship with the incumbent and the belief that the most of generated value (i.e., financial) of the developed new product will be taken unfairly by the incumbent (see similar view in Prashantham and Birkinshaw 2008; Fischer and Reuber 2004). Respondent C stated that “...our contract was not fair. In the early contract, we did not have accurate information about the added value of our technology in the market thus we could not be able to clear our right in the deal." Respondent C emphasized that the incumbent was the main beneficiary of their effort and inventions. Despite several negotiation meetings to change their contract terms, the incumbent does not show any flexibility. Consequently, Respondent $\mathrm{C}$ decided to take an alternative approach and commercialize the developed new product to other potential customers. The incumbent reacted to this behavior severely by terminating the relationship and taking legal acts. Following these tensions, Respondent $\mathrm{C}$ could not commercialize the developed new product and became bankrupt.

We conclude that forcing a new venture to engage in a strategic alliance with less transparency regarding the partner's fair contributions and benefits might be an effective approach at the early stages of NPD. However, new ventures do not tolerate unfair treatment in long-term when they successfully turn their inventions to commercializable products and gain more managerial experience (i.e., project management, negotiation). Our findings show that the new venture's attempt to change the initial contract and relationship characteristics (i.e., power imbalance, unequal distribution of benefits) does not always have the intended outcomes. The incumbent may stick to the initial contract when the mutual trust, commitment, and dependence are not strong enough to make them be more flexible. In this sense, Respondent $\mathrm{C}$ harmed the relationship when it undertook hostile negotiation approach and opportunistic behavior rather than a conciliatory approach by building relational bonds and emphasizing the value of long-term relationships.

\section{Discussions}

Our study contributes to the literature by investigating the dynamic of business relationships between new ventures and incumbent across the stages of a collaborative NPD project. Researchers have studied the importance of business relationships for new ventures (i.e., Carayannopoulos 2009; Haeussler et al. 2012), however little attention is given to the evolving nature asymmetric relationships with incumbents. We undertake the dynamic views of business relationship to reveal when and under what conditions new ventures undertake either transactional contract or alliance approach to collaboratively develop new products with an incumbent. Although the successful management of business relationships with an incumbent is vital for the new venture's survival, 
managing these asymmetric relationships is challenging for entrepreneurs with trivial experience and negotiation power. Our findings advance the literature on business relationships in two ways.

First, in contrast to the extant literature that show business relationships commonly evolve from transactional contract to alliance over time (Jap and Anderson 2007; Marion et al. 2015), we demonstrate that the asymmetric relationships between new ventures and incumbents across the stages of a collaborative NPD project may follow a different trajectory (see Fig. 1). We show that most of the new ventures tend to initiate a transactional relationship with incumbents to outsource non-core development activities while protecting their patents from knowledge leak. However, new ventures change their approach when they realize that incumbents do not invest their resource without building mutual trust and long-term relationships. Consequently, most of the studied new ventures undertake the alliance approach to gain trust and encourage the incumbent to invest resources during the discovery stage. New ventures with less flexibility spent considerable time in negotiating with the incumbent, while they lack negotiation skills and resources required for NPD. In line with Marion et al. (2015), we find that new ventures gradually undertake the alliance approach during discovery and development stages as mutual trust and relational norms are developed. Contrary to Marion et al. (2015), we find that when prototypes were successfully developed, studied new ventures attempted to undertake transactional contract approach again to renegotiate each party's responsibilities and the fair share benefits of the relationship. The latter evolution is due changing the level of partners' dependence and resource investment required to commercialize the developed new product. Our research extends works of Pérez et al. (2012) and Oukes et al. (2017) by showing that new ventures undertake 'power change' behavior when they successfully develop prototypes and gain legitimacy and trust of the incumbent. Our findings advance the literature on the dark side of business relationships by showing that new ventures and incumbents could maintain and expand their relationship when the incumbent appreciates the new venture's grow, demonstrates flexibility to re-negotiate the expectations, and shares the fair benefits during the commercialization stage.

Second, we also discovered that the relationship between new ventures and incumbents is vulnerable during the commercialization stage despite the considerable investment (i.e., fund, effort, time) by both sides to develop a new product. The extant literature shows that RSIs increase switching costs and can act as the mutual hostage mechanism, which encourages partners to safeguard their mutual investments and benefits (Jap and Anderson 2007; Palmatier et al. 2007). However, we find that RSIs do not save a relationship, even if most of the investment were unilaterally made by the new venture and exit from the relationship harm their survival. We extend Heirati et al. (2018) who argue that the relative importance of transactional factors decreases over time compare to inter-organizational trust. Particularly, we show that new ventures are likely to terminate the relationship when they are forced by the incumbent to continue an asymmetric relationship and receive unequal benefits from the relationship. The incumbent's lack of flexibility to acknowledge the incumbent's effort and share the fair benefits will damage the relationship's trust and commitment. To compensate unfair distribution of benefits, the new venture may undertake opportunistic behavior by commercializing the developed product to other potential clients. Our findings advance the literature by showing that the exchange partner's inflexibility to undertake the transactional contract approach in combination with relational mechanisms to re-negotiate their expectations can damage the relationship. Although incumbents are usually in the power-advantaged position visà-vis new ventures, their flexibility and relational capability are essential to the success of the relationship. 


\section{Managerial implications}

Our findings provide implications for both entrepreneurs and managers of incumbents. New ventures must continuously assess the level dependence and interorganizational trust in the relationship and their negotiation power relative to the incumbent. Such assessment must be based not only on the value of the resources they control, but also on the level of interdependence (i.e., the importance of their innovations for the incumbent) and commitment to achieve shared objectives. A narrow focus on the resource dependency may lead to overestimating the incumbent's power in the relationship. The new venture's perception of imbalance power and being forced to invest more in the relationship compared to the incumbent can lead to dissatisfaction and conflicts over time. To minimize power imbalance and develop mutually beneficial relationships, entrepreneurs should be more flexible in negotiations, develop relational bonds, and gain legitimacy (i.e., through successful development of prototypes) during early stages of NPD. During the later stages of NPD, entrepreneurs can gradually prove the value of their innovation capability to the incumbent and undertake contractual mechanisms to protect their patents and ensure fair distribution of the relationship's benefits. Undertaking different tactics and developing relational bonds may change the incumbent's behavior and convince them to comply with the new venture's demands during the commercialization stage.

We also warn entrepreneurs that attempts to alter the relationship characteristics (i.e., power imbalance, unequal distribution of benefits) does not always lead to intended outcomes. Incumbents may stick to the initial contract that new ventures were forced to accept at the beginning of the relationship. When new ventures and incumbents collaboratively develop a new product and prepare for commercialization, they still need to build mutual trust and transparency regarding their roles and expected fair benefits. Entrepreneurs should undertake a conciliatory approach (see Oukes et al. 2017) by emphasizing the value of long-term relationships and avoid opportunistic or hostile behaviors (i.e., selling products to competitors). The opportunistic behavior and hostile negotiation tactics often harm the relationship. In turn, the incumbent partner may respond aggressively, especially when relational bonds are not developed and power imbalance exists. When a new venture fails to extract the intended benefits from the relationship and undertake opportunistic or hostile behavior, the termination of the relationships is likely. If the new venture uses conciliatory tactics to develop relational bonds and demonstrate their commitment to the relationship, the incumbent partner is more likely to respond gently and re-negotiate the relationship's terms and expectation.

\section{Future research and limitations}

Due to using case studies, this study is not without limitations. Following Marion et al. (2015) and Yin (2014), we employ a longitudinal multiple case study approach. The research design was deemed appropriate for the objectives set: to explore the evolutions of relationships between new ventures and incumbents across different stages of a collaborative NPD project. Although using longitudinal multiple cases increases the replicability of the findings, our study is based on a sample of technology-intensive new ventures. Therefore, we should be cautious of generalizing our conclusions to other sectors (i.e., less technology-intensive industries, service sector). Future research could extend our study by investigating the dynamic of relationships between new ventures and incumbents in the context of knowledge-intensive firms (i.e., professional services) that rely more on intellectual investments and share of tacit knowledge and competencies. Further, we collected data from the new venture's perspective, but it is conceivable that incumbents may have a different perspective and undertake other governance 
mechanisms to develop their relationships with new ventures. Therefore, another potential avenue for future research is to integrate dyadic perspectives of new ventures and incumbents to provide a more advanced view of the dynamic of business relationships across NPD stages. Finally, the entrepreneurship literature asserts that the entrepreneur's personality can affect their decision and coping strategies, however little attention is given to how entrepreneurs' personality can affect their choice of different governance mechanisms. Future research can investigate how the personality of entrepreneurs affect their flexibility to adopt different governance mechanisms when developing an asymmetric relationship with incumbents.

\section{References}

Ansari, S., \& Krop, P. (2012). Incumbent performance in the face of a radical innovation: Towards a framework for incumbent challenger dynamics. Research Policy, 41(8), 1357-1374.

Barczak, G., Griffin, A., \& Kahn, K. (2009). Perspective: trends and drivers of success in NPD practices: results of the 2003 PDMA best practices study. Journal of Product Innovation Management, 26(1), 3-23.

Cao, Z., \& Lumineau, F. (2015). Revisiting the interplay between contractual and relational governance: A qualitative and meta-analytic investigation. Journal of Operations Management, 33, 15-42.

Carayannopoulos, S. (2009). How technology-based new firms leverage newness and smallness to commercialize disruptive technologies. Entrepreneurship Theory and Practice, 33(2), 419-438.

Creswell, J. (2013). Qualitative inquiry and research design: Choosing among approaches, 3rd Edition, Sage, Thousand Oaks, California.

Deeds, D., \& Hill, C. (1998). An examination of opportunistic action within research alliances-The analysis of discrete structural alternatives. Journal of Business Venturing, 14(2), 141-163.

Eisenhardt, K. M. (1989). Building Theories from Case Study Research. Academy of Management Review, 14, 532-550.

Eisenhardt, K., \& Graebner, M. (2007). Theory building from cases: opportunities and challenges. Academy of Management Journal, 50(1), 25-32.

Enkel, E., Gassmann, O., \& Chesbrough, H. (2009). Open R\&D and open innovation: Exploring the phenomenon. R\&D Management, 39(4), 311-316.

Fischer, E., \& Reuber, A. R. (2004). Contextual antecedents and consequences of relationships between young firms and distinct types of dominant exchange partners. Journal of Business Venturing, 19(5), 681-706.

Genet, C., Errabi, K., \& Gauthier, C. (2012). Which model of technology transfer for nanotechnology? A comparison with biotech and microelectronics. Technovation, 32(3-4), 205-215.

Grant, R., \& Baden-Fuller, C. (2004). A knowledge accessing theory of strategic alliances. Journal of Management Studies, 41(1), 61-84.

Haeussler, C., Patzelt, H., \& Zahra, S. (2012). Strategic alliances and product development in high technology new firms: The moderating effect of technological capabilities. Journal of Business Venturing, 27(2), 217233.

Hagedoorn, J., \& Hesen, G. (2007). Contract law and the governance of inter-firm technology partnerships-An analysis of different modes of partnering and their contractual implications. Journal of Management Studies, 44(3), 342-366.

Heirati, N., Henneberg, S., Richter, A., \& Harste, R. (2018). Differential importance of social and economic determinants of relationship performance in professional services. Industrial Marketing Management, InPress.

Heirati, N., \& Siahtiri, V. (2017). Driving service innovativeness via collaboration with customers and suppliers: Evidence from business-to-business services. Industrial Marketing Management, InPress.

Hienerth, C., Lettl, C., \& Keinz, P. (2014). Synergies among producer firms, lead users, and user communities: The case of the LEGO producer-user ecosystem. Journal of Product Innovation Management, 31(4), 848866.

Jap, S., \& Anderson, E. (2007). Testing a life-cycle theory of cooperative interorganizational relationships: Movement across stages and performance. Management Science, 53(2), 260-275. 
La Rocca, A., Moscatelli, P., Perna, A. \& Snehota, I. (2016). Customer involvement in new product development in B2B: The role of sales. Industrial Marketing Management, 58), 45-57.

Mangematin, V., \& Walsh, S. (2012). The future of nanotechnologies. Technovation, 32(3-4), 157-160.

Marion, T., Eddleston, K., Friar, J., \& Deeds, D. (2015). The evolution of interorganizational relationships in emerging ventures: An ethnographic study within the new product development process. Journal of Business Venturing, 30(1), 167-184.

Nikulainen, T. (2010). Identifying nanotechnological linkages in the Finnish economy-An explorative study. Technology Analysis and Strategic Management, 22(5), 513-531.

Oukes, T., von Raesfeld, A., Groen, A., \& PCDIAB Consortium. (2017). Power in a startup's relationships with its established partners: Interactions between structural and behavioral power. Industrial Marketing Management, InPress.

Padula, G. (2008). Enhancing the innovation performance of firms by balancing cohesiveness and bridging ties. Long Range Planning, 41(4), 395-419.

Palmatier, R., Dant, R., \& Grewal, D. (2007). A comparative longitudinal analysis of theoretical perspectives of interorganizational relationship performance. Journal of Marketing, 71(4), 172-194.

Palmatier, R., Houston, M., Dant, R., \& Grewal, D. (2013). Relationship velocity: Toward a theory of relationship dynamics. Journal of Marketing, 77(1), 13-30.

Panico, C. (2017). Strategic interaction in alliances. Strategic Management Journal, 38(8), 1646-1667.

Pérez, L., Florin, J., \& Whitelock, J. (2012). Dancing with elephants: The challenges of managing asymmetric technology alliances. Journal of High Technology Management Research, 23(2), 142-154.

Prashantham, S., \& Birkinshaw, J. (2008). Dancing with gorillas: How small companies can partner effectively with MNCS. California Management Review, 51(1), 6-23.

Ring, P. S., \& Van de Ven, A. H. (1994). Developmental processes of cooperative interorganizational relationships. Academy of management review, 19(1), 90-118.

Rothaermel, F., \& Thursby, M. (2007). The nanotech versus the biotech revolution: Sources of productivity in incumbent firm research. Research Policy, 36(6), 832-849.

Schleimer, S., \& Faems, D. (2016). Connecting interfirm and intrafirm collaboration in NPD projects: Does innovation context matter?. Journal of Product Innovation Management, 33(2), 154-165.

Sivadas, E., \& Dwyer, F. (2000). An examination of organizational factors influencing new product success in internal and alliance-based processes. Journal of marketing, 64(1), 31-49.

Villena, V., Revilla, E., \& Choi, T. (2011). The dark side of buyer-supplier relationships: A social capital perspective. Journal of Operations Management, 29(6), 561-576.

Yin, R. (2014). Case Study Research: Design and Methods, 5th Edition, Sage, Thousand Oaks, California.

Zhang, J., Watson IV, G., Palmatier, R., \& Dant, R. (2016). Dynamic relationship marketing. Journal of Marketing, 80(5), 53-75. 
Fig. 1 Relationships evolution trajectory across NPD stages

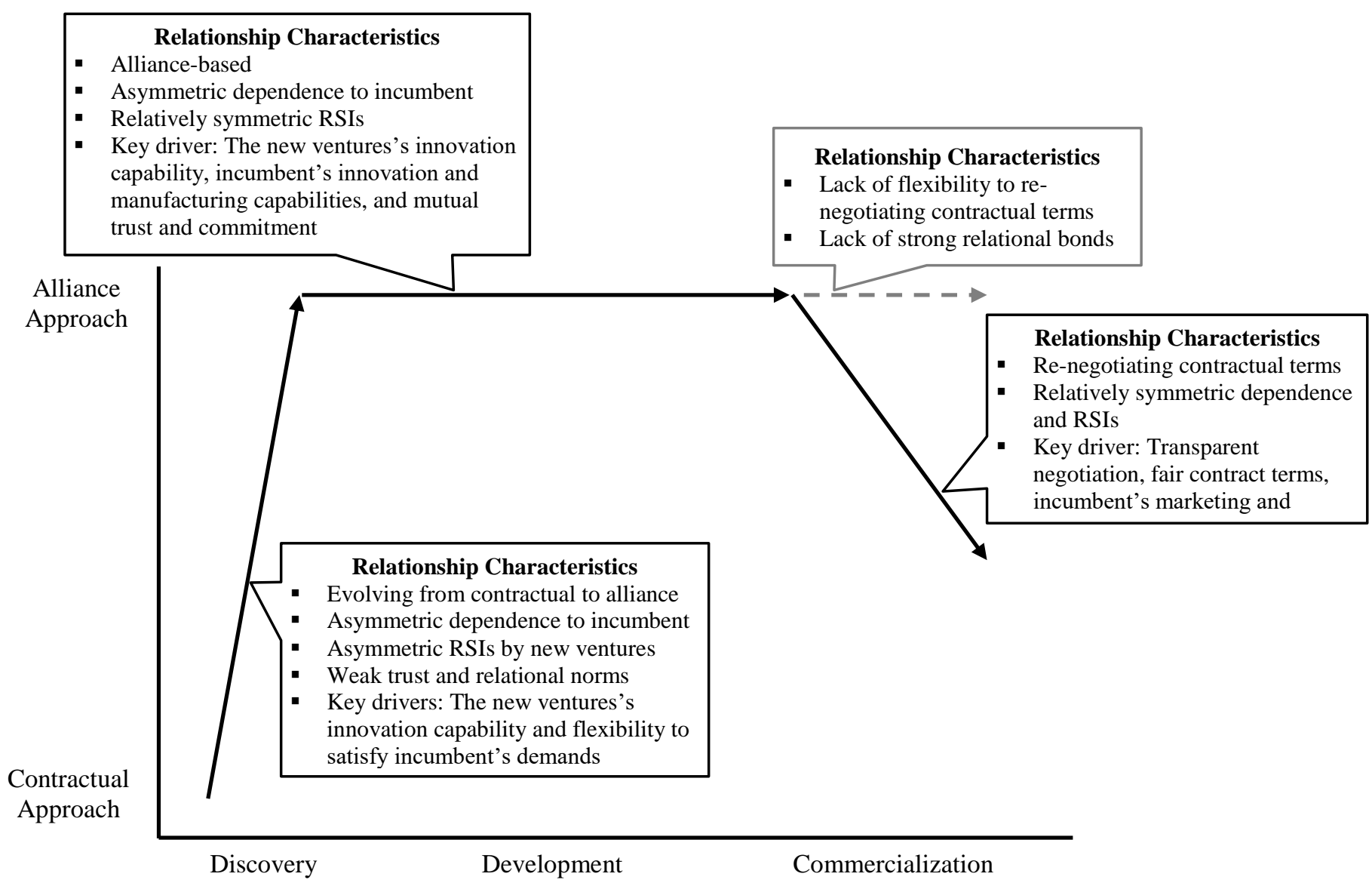


Table 1. Business relationship governance approaches

\begin{tabular}{|c|c|c|c|}
\hline $\begin{array}{l}\text { Governance } \\
\text { approaches }\end{array}$ & Definition & Focus & Limitations \\
\hline Transactional & $\begin{array}{l}\text { Transactional governance (also called transactional } \\
\text { contract or contractual governance) refers to formal rules } \\
\text { that safeguard business partners against contractual } \\
\text { hazards (i.e., opportunism and conflict). Contractual } \\
\text { hazards can arise from unilateral investments specific to } \\
\text { the transaction parties (Hagedoorn and Hesen 2007; Cao } \\
\text { and Lumineau 2015). } \\
\text { Types: } \text { Transactional contracts such as outsourcing, } \\
\text { franchising, licensing contracts }\end{array}$ & $\begin{array}{l}\text { This approach building on the transaction cost economy } \\
\text { (TCE) emphasizes on (a) minimizing operation costs, (b) } \\
\text { reducing knowledge/patent leak, and (c) selecting a } \\
\text { contractual governance structures to develop business } \\
\text { relationships. } \\
\text { Transactional contracts commonly define the expected } \\
\text { outputs, monitoring mechanisms, and the exchange partners } \\
\text { duties and rights. }\end{array}$ & $\begin{array}{l}\text { Incomprehensiveness: Impossible to predict } \\
\text { all contingencies } \\
\text { - Mismatch of contract application by } \\
\text { business partners } \\
\text { - Ineffective mechanism to build inter- } \\
\text { organizational trust } \\
\text { - Less effective for relationship involved } \\
\text { collaborative learning (i.e., joint R\&D) }\end{array}$ \\
\hline Relational & $\begin{array}{l}\text { Relational governance refers to the extent to which a } \\
\text { business relationship is governed by social and relational } \\
\text { norms, such as mutual trust, commitment, and } \\
\text { interdependence (Palmatier et al. 2007; Cao and } \\
\text { Lumineau, 2015; Panico, 2017). } \\
\text { Types: Alliances such as strategic partnership and joint } \\
\text { R\&D }\end{array}$ & $\begin{array}{l}\text { This approach building on the social exchange theory (SET) } \\
\text { relies on informal structure and self-enforcement of each } \\
\text { party. It focuses on building mutual trust and commitment to } \\
\text { facilitate knowledge share and collaborative learning between } \\
\text { exchange partners. } \\
\text { This approach is built on unspecified obligation and } \\
\text { reciprocity. To prove trustworthiness and commitment, } \\
\text { exchange parties will regularly invest in the relationship } \\
\text { beyond the contractual obligations. Cooperative parties should } \\
\text { follow the rules of reciprocity to nurture mutual trust and } \\
\text { relational norms. }\end{array}$ & $\begin{array}{l}\text { - Take time to be developed } \\
\text { - Can be destroyed easily by betrayal } \\
\text { - Can be abused by opportunism when formal } \\
\text { monitoring is replaced by excessive trust } \\
\text { - Lack of transparency in the presence of } \\
\text { conflicts }\end{array}$ \\
\hline
\end{tabular}


Table 2. The sample characteristics

\begin{tabular}{|c|c|c|c|c|c|c|}
\hline Case & Investment & Area & $\begin{array}{c}\text { Age of } \\
\text { Founder(s) }\end{array}$ & $\begin{array}{c}\text { No. of } \\
\text { Founder(s) }\end{array}$ & $\begin{array}{l}\text { Founder(s) } \\
\text { Education }\end{array}$ & $\begin{array}{c}\text { New ventures growth } \\
\text { (as of 2017) }\end{array}$ \\
\hline A & Self-financed/ Governmental loan & Producing laboratorial electro spinning instrument & Late $30 \mathrm{~s}$ & 3 & $1 \mathrm{PhD} 2 \mathrm{MSc}$ & $\begin{array}{l}\text { Become a medium-sized firm - } \\
\text { Export to many countries }\end{array}$ \\
\hline B & Self-financed/ Governmental loan & Producing nanomaterial & Early $30 \mathrm{~s}$ & 2 & $1 \mathrm{PhD} 1 \mathrm{MSc}$ & $\begin{array}{l}\text { Become a medium-sized firm - } \\
\text { Export to many countries }\end{array}$ \\
\hline $\mathrm{C}$ & Self-financed & Producing nano-diamond & Late $20 \mathrm{~s}$ & 1 & $1 \mathrm{BSc}$ & Bankrupted in 2015 \\
\hline $\mathrm{D}$ & Self-financed/ Governmental loan & Physical vapor deposition process & Early 30 s & 4 & $1 \mathrm{PhD} 3 \mathrm{MSc}$ & $\begin{array}{l}\text { Small-sized firm with growing } \\
\text { market }\end{array}$ \\
\hline $\mathrm{E}$ & Self-financed & Nano cavitation technology & Late $30 \mathrm{~s}$ & 2 & $1 \mathrm{PhD} 1 \mathrm{MSc}$ & $\begin{array}{l}\text { Small-sized firm with growing } \\
\text { market }\end{array}$ \\
\hline $\mathrm{F}$ & Self-financed/ Governmental loan & Advanced hard coating & Late $30 \mathrm{~s}$ & 2 & $1 \mathrm{PhD} 1 \mathrm{MSc}$ & $\begin{array}{l}\text { Become a medium-sized firm with } \\
\text { growing market }\end{array}$ \\
\hline G & Self-financed & Nanomaterials & Late $30 \mathrm{~s}$ & 2 & $2 \mathrm{MSc}$ & $\begin{array}{l}\text { Small-sized firm with growing } \\
\text { market }\end{array}$ \\
\hline
\end{tabular}

Table 3. Summary of studies collaborative NPD projects

\begin{tabular}{|c|c|c|c|c|c|c|}
\hline \multirow{2}{*}{ Case } & \multirow{2}{*}{ Sector } & \multirow{2}{*}{ NPD Outcomes } & \multicolumn{3}{|c|}{ Governance Approach Across NPD Stages } & \multirow{2}{*}{ Project Continuity } \\
\hline & & & Discovery & Development & Commercialization & \\
\hline A & Air filtration & $\begin{array}{l}\text { Industrial electro spinning instrument was produced to upgrade the } \\
\text { turbine's filter class. }\end{array}$ & Contractual & Alliance & $\begin{array}{l}\text { Alliance to Contractual } \\
\text { (Mainly contractual) }\end{array}$ & Continue - Further upgrades \\
\hline $\mathrm{B}$ & Polymer Pipes & $\begin{array}{l}\text { Nano master batch was formulated to increase mechanical strength } \\
\text { of silencing pipes. }\end{array}$ & $\begin{array}{c}\text { Contractual to } \\
\text { Alliance }\end{array}$ & Alliance & $\begin{array}{l}\text { Alliance to Contractual } \\
\text { (Mainly alliance) }\end{array}$ & Continue - Mass production \\
\hline $\mathrm{C}$ & Automobile oil & Qualified oil was produced with Nano-diamond additive. & Contractual & $\begin{array}{l}\text { Contractual to } \\
\text { Alliance }\end{array}$ & Dissolution & Terminated \\
\hline $\mathrm{D}$ & Turbines & $\begin{array}{l}\text { Increased blades' hardness, toughness and corrosion resistance } \\
\text { with nanostructure coating. }\end{array}$ & $\begin{array}{l}\text { Contractual to } \\
\text { Alliance }\end{array}$ & Alliance & $\begin{array}{l}\text { Alliance to Contractual } \\
\text { (Mainly alliance) }\end{array}$ & Continue - Further upgrades \\
\hline $\mathrm{E}$ & Water filtration & $\begin{array}{l}\text { Produced Nano cavitation device to oxidize of heavy metals and } \\
\text { remove them from drinking water. }\end{array}$ & Alliance & Alliance & $\begin{array}{l}\text { Alliance to Contractual } \\
\text { (Mainly contractual) }\end{array}$ & Continue - New NPD projects \\
\hline $\mathrm{F}$ & $\begin{array}{c}\text { Automobile } \\
\text { manufacturing }\end{array}$ & $\begin{array}{l}\text { Produced nano-composites to increase the level of hardness and } \\
\text { corrosion/erosion resistance. }\end{array}$ & Contractual & Alliance & $\begin{array}{l}\text { Alliance to Contractual } \\
\text { (Mainly contractual) }\end{array}$ & Continue - Further upgrades \\
\hline G & Medical & $\begin{array}{l}\text { Used fluorescent silica nanoparticles in immune chromatographic } \\
\text { tests. }\end{array}$ & Contractual & Alliance & $\begin{array}{l}\text { Alliance to Contractual } \\
\text { (Mainly alliance) }\end{array}$ & Continue - Mass production \\
\hline
\end{tabular}

